\title{
SOLID STATE CULTURE CONDITIONS FOR COMPOSTING SEWAGE SLUDGE
}

\author{
N.A. KABBASHI ${ }^{1}$, A. FAKHRU'L-RAZI ${ }^{2}$ AND K.B. RAMACHANDRAN ${ }^{3}$ \\ ${ }^{1}$ Department of Biotechnology Engineering, International Islamic University Malaysia, Jalan \\ Gombak, 53100 Kuala Lumpur. Malaysia. \\ ${ }^{2}$ Department of Chemical \& Environmental Engineering, University Putra Malaysia, 43400 \\ UPM Serdang, Malaysia. \\ ${ }^{3}$ Department of Chemical Engineering, University of Malaya, 50602, Kuala Lumpur, \\ Malaysia. \\ e-mail:alkabbashi@yahoo.com
}

\begin{abstract}
Composting is applied to treat sewage sludge from treatment plants to enhance its quality and suitability for agricultural use. In this work the optimal conditions for composting sewage sludge from domestic wastewater treatment plants in a horizontal drum bioreactor (HDB) were investigated. This study investigated the physico-chemical conditions affecting the use of filamentous fungi in composting. The average number of faecal coliforms was $2.3 \times 10^{7}$ bacteria/g waste dry weight at the beginning of the composting process, and decreased considerably to $8.2 \times 10^{3}, 8.1 \times 10^{3}, 8.5 \times 10^{3}, 8.0 \times 10^{3}$, and $8.4 \times 10^{3}$ bacteria/g, respectively for experiments $\mathrm{T} 1$ to $\mathrm{T} 5$. This decrease was presumably the result of raising temperature. The phase of hygienisation was marked by a very significant decrease in the number of $E$. coli cells $\left(1.8 \times 10^{7}\right.$, to $3.7 \times 10^{3}, 3.8 \times 10^{3}, 3.3 \times 10^{3}, 3.2 \times 10^{3}$, and $3.6 \times 10^{3}$ bacteria/g) for T1 to T5 experiments, respectively: A second aspect was the investigation of a possible reduction of hazardous pollutants. The highest concentration was for $\mathrm{Fe}$ and the lowest for $\mathrm{Pb}$, showing that $\mathrm{Fe}$ is the most loosely bound to the sewage sludge organic matrix and $\mathrm{Pb}$ the most strongly bound, the $\mathrm{Cd}$ reduction by composting was more than $50 \%$.
\end{abstract}

Keywords: Sewage sludge, compost, horizontal drum bioreactor, hazardous.

\section{INTRODUCTION}

The development of appropriate strategies for treatment and disposal of sewage sludge is a major problem in all countries throughout the world. Sludge treatment and disposal not only represents about half of the total costs of municipal wastewater collection, but it is also strongly regulated, more so than almost any other form of waste, and readily attracts adverse media and public attention. Thus, the challenge for wastewater authorities is to find affordable, sustainable and safe approaches to sludge management, which are also publicly accepted [1]. 
In its untreated form, wastewater cannot be disposed off for several reasons. First, the biological decomposition of the organic materials in wastewater consumes oxygen and thus reduces the quantity available in the receiving waters for the aquatic life. The decomposition also produces large quantities of malodorous gases. Secondly, the numerous pathogenic or disease causing microorganisms in untreated wastewater are health hazards to human beings. Third, its toxic compounds, especially heavy metals, can be dangerous to both plants and animals, and finally the presence of phosphates and nitrogen may lead to uncontrolled growth of aquatic plants [2].

Din and Hamid[3] studied the history of wastewater treatment plant of Kuala Lumpur city, Malaysia, which provided a good illustration of the above case. The annual sludge volume produced currently is estimated to be 3 million cubic meters and requires some 600,000 -tanker trips to transport the sludge to designated treatment and disposal sites. By the year 2020, the volume is estimated to increase to 7 million cubic meters, which will require almost 1.4 million tanker trips to manage. The volume of sludge generated depends on the level and process of wastewater treatment. There may also be seasonal variability due to rain and runoff entering the sewers or in sewage treatment plants (STPs) that serve tourist centers and schools, which cater to a variable population density, throughout the year. Sludge production quantities can be estimated from the STPs design capacity and treatment process.

Composting is becoming a more acceptable alternative for the treatment of sewage sludge in many municipalities due to the potential use of the composting product for land application [4]. It has become a well-established process for adding value to a large and growing number of organic byproducts. Even so, composting systems and uses for compost are still evolving. Design, operation and control issues remain key factors leading to the success or failure of the process. Environmental issues, product quality and utilization strategies have not yet been fully optimized for many applications to allow the use of composting process on a sustainable and economic basis. Recent advances in the design, construction and operation of municipal, industrial and agricultural facilities have brought significant improvements to this field. New techniques for monitoring microbial diversity, specific pathogens and beneficial microorganisms have led to a better understanding of the composting process.

\section{MATERIALS}

The sewage sludge used in this study was collected from Taman Sri Nanding and Taman Koperasi Indah Water Konsortium (IWK) treatment plants, Malaysia. To characterize the sludge, they were analyzed for moisture content, electrical conductivity, $\mathrm{pH}$, organic carbon, nutrients $(\mathrm{N}, \mathrm{P}, \mathrm{K}, \mathrm{Ca}$, and $\mathrm{Mg}$ ) and heavy metal content. Each analysis was replicated three times. Table 1 gives the characteristics of the raw sludge along with that of sawdust. Sawdust was used as a bulking agent in this study. The sludge had a high moisture content around $80 \%$ to $82 \%$ and a low $\mathrm{C} / \mathrm{N}$ ratio of 7 to 8.5 . Both sludges had more or less similar characteristics. However the $\mathrm{pH}$ of sludge from Taman Sri Nanding was lower than that of Taman Koperasi; In addition, heavy metal content of the sludges showed some differences. Sawdust had low moisture content of $17 \%$ and a high $\mathrm{C} / \mathrm{N}$ ratio of 184 . Hence sawdust was homogenized with the sludge to increase the 
$\mathrm{C} / \mathrm{N}$ ratio of the sludge. This also reduced the moisture content to the optimal level for composting.

The sewage sludge and sawdust was analyzed for the following parameters: moisture content $\left(105^{\circ} \mathrm{C}\right.$ for $\left.24 \mathrm{~h}\right)$ using Gravimetric Method [5]; $\mathrm{pH}$ (dilution 1:25 w/v) using a $\mathrm{pH}$ electrode; electrical conductivity (dilution 1:10 w/v) using a conductivity electrode [6]; organic matter and ash content $\left(550^{\circ} \mathrm{C}\right.$ for $\left.6 \mathrm{~h}\right)$; the total organic carbon $\mathrm{C}$ was estimated from the organic matter value using the factor of 1.82 , which is often used for municipal solid waste [7]; the theoretical total $\mathrm{N}$ concentration of the sewage sludge was calculated by adding the Kjeldahl nitrogen with the $\left(\mathrm{NO}_{3}{ }^{-}+\mathrm{NO}_{2}{ }^{-}\right)-\mathrm{N}$ [8]; the $\mathrm{C} / \mathrm{N}$ ratio was then computed based on the concentration of total organic $\mathrm{C}$ and $\mathrm{N}$. Trace elements $(\mathrm{Cd}, \mathrm{Fe}, \mathrm{Cu}, \mathrm{Zn}, \mathrm{Pb}, \mathrm{Cr}, \mathrm{Ca}, \mathrm{Mg}$, $\mathrm{Mn}$ and $\mathrm{K}$ ); in addition to potassium, calcium, and magnesium content were determined by using the (Dry Digestion Method), and water-extractable (1:10 w/v) (atomic absorption spectrophotometer); and evaluation of microbiological parameter performed as recommended in Standard Methods. Three efficient cellulolytic cultures were used in this study. The first two Mucor hiemalis and Trichoderma harzianum were isolated and screened at Universiti Putra Malaysia Biochemical Engineering laboratory and the third was Phanerochaete chrysosporium ATCC 24725. The strains used are non-toxic and do not produce any toxic by product during fermentation processes. They are capable of utilizing lignin, grow on lignocellulosic materials, and degraded oil. The microbial collection was obtained from UPM and the Indian Agricultural Research Institute, New Delhi, India.

The mean and standard deviation of the three replicated were reported for all parameters measured. To compare the variations in composting at different positions, oneway analysis of variance (ANOVA) statistical testing was performed [11].

\subsection{Faecal Coliforms}

Dunnigan and Dick [12] mentioned that raw sewage water contains many microorganisms such as bacteria, viruses and parasitic protozoa, which may be pathogenic. Pathogen removal or reduction before land application is therefore necessary to minimize the potential risk on human and animal [13]. Based on Jenkins [14], pathogen reduction can occur by either dehydration or biodegradation.

\section{EXPERIMENTAL METHODS}

\subsection{Composition Studies}

A control experiment and six other experiments were carried out to determine the optimal operating conditions and operational strategies to compost the sewage sludge from treatment plant (Table 2). The objective of the control was to find out the changes that would occur during composting of sewage sludge from treatment plant and compare them with other experiments, while experiments T2 to T6 were to study the effect of inoculating various microorganisms on the progress of composting and to determine the best and most efficient inoculum. 
Table 1: Characteristics of sewage sludge, sawdust and soil.

\begin{tabular}{|c|c|c|c|c|}
\hline Parameters & $\begin{array}{l}\text { Sewage sludge } \\
\text { Taman Koperasi }\end{array}$ & $\begin{array}{c}\text { Sewage sludge Taman } \\
\text { Sri Nanding }\end{array}$ & Bulking agent (Sawdust) & Typical value in soil $*$ \\
\hline Moisture content (\%) & $82 \pm 0.32^{\mathrm{a}}$ & $80.2 \pm 0.057$ & $10-20$ & na \\
\hline $\mathrm{pH}$ & $7.27 \pm 0.012$ & $4.29 \pm 0.0057$ & $4.5 \pm 0.058$ & 5.0 \\
\hline $\mathrm{EC}\left(\mathrm{dSm}^{-1}\right)$ & $1.83 \pm 0.015$ & $1.8 \pm 0.015$ & $0.02 \pm 0.003$ & 0.1 \\
\hline Carbon $(\%)$ & $40.39 \pm 0.0466$ & $52.47 \pm 0.029$ & $57-58.33$ & 3.9 \\
\hline $\mathrm{C} / \mathrm{N}$ ratio & $7.21 \pm 0.038$ & $8.5 \pm 0.0577$ & $166.6-285$ & 11 \\
\hline Total Solids (\%) & $22.12 \pm 0.015$ & $19.78 \pm 0.122$ & $85.6 \pm 0.058$ & nd \\
\hline \multicolumn{5}{|l|}{ Macro nutrients } \\
\hline $\mathrm{N}(\%)$ & $5.6 \pm 0.058$ & $6.2 \pm 0.1$ & $0.2-0.35$ & 0.4 \\
\hline $\mathrm{P}(\%)$ & $1.6 \pm 0.058$ & $1.52 \pm 0.009$ & $1.17 \pm 0.017$ & $0.05-0.2$ \\
\hline $\mathrm{K}(\%)$ & $0.09 \pm 0.011$ & $0.05 \pm 0.02$ & $0.0194 \pm 5.5 \times 10^{-4}$ & $0.04-3$ \\
\hline $\mathrm{Ca}(\%)$ & $0.15 \pm 7.64 \times 10^{-3}$ & $0.89 \pm 0.06$ & $0.0158 \pm 2.19 \times 10^{-4}$ & $0.7-50$ \\
\hline $\operatorname{Mg}(\%)$ & $0.03 \pm 2.88 \times 10^{-3}$ & $0.07 \pm 4.619$ & $0.0039 \pm \times 10^{-3}$ & $0.06-6$ \\
\hline \multicolumn{5}{|l|}{ Micro elements } \\
\hline $\mathrm{Cu}(\mathrm{ppm})$ & $111.4 \pm 0.058$ & $49.83 \pm 0.15$ & $4.8 \pm 0.058$ & $2-100$ \\
\hline $\mathrm{Cd}(\mathrm{ppm})$ & $10.2 \pm 0.24$ & $1.13 \pm 0.015$ & $6.5 \pm 0.115$ & $0.01-7$ \\
\hline $\mathrm{Zn}(\mathrm{ppm})$ & $511.8 \pm 0.0577$ & $2893.53 \pm 0.19$ & $8.2 \pm 0.145$ & $10-300$ \\
\hline $\mathrm{Mn}(\mathrm{ppm})$ & $606.0 \pm 0.58$ & $315.53 \pm 0.5$ & $4.6 \pm 0.5$ & $100-4000$ \\
\hline $\mathrm{Cr}(\mathrm{ppm})$ & $27.0 \pm 1.5$ & $73.76 \pm 0.12$ & $14.6 \pm 0.0577$ & $5-3000$ \\
\hline $\mathrm{Fe}(\mathrm{ppm})$ & $3586.0 \pm 0.88$ & $4930.0 \pm 1$ & $402.9 \pm 0.0577$ & $700-5500$ \\
\hline $\mathrm{Pb}(\mathrm{ppm})$ & $51.7 \pm 0.153$ & $55.2 \pm 0.088$ & $16.0 \pm 0.115$ & na \\
\hline $\mathrm{Ni}(\mathrm{ppm})$ & $497.6 \pm 0.01$ & na & $293.8 \pm 0.0577$ & na \\
\hline
\end{tabular}

* Soil (Adriano et al., 1980) [21]

na $=$ not analyzed

$\mathrm{EC}=$ Electrical conductivity

${ }^{\text {a }}$ Mean \pm standard error 
Table 2: $\quad$ Evolution during the composting process (Faecal Coliform and E. Coli).

\begin{tabular}{ccccc}
\hline Experiment & $\begin{array}{c}\text { Before } \\
\text { composting } E . \\
\text { coli } \\
\text { (bacteria/g) }\end{array}$ & $\begin{array}{c}\text { After } \\
\text { Composting } \\
\text { E. coli } \\
\text { (bacteria/g) }\end{array}$ & $\begin{array}{c}\text { Before composting } \\
\text { Faecal coliform } \\
\text { (bacteria/g) }\end{array}$ & $\begin{array}{c}\text { After } \\
\text { Composting } \\
\text { Faecal coliform } \\
\text { (bacteria/g) }\end{array}$ \\
\hline SS & $1.8 \times 10^{7}$ & $1.8 \times 10^{7}$ & $2.3 \times 10^{7}$ & $2.3 \times 10^{7}$ \\
Control & $1.8 \times 10^{7}$ & $1.8 \times 10^{7}$ & $2.3 \times 10^{7}$ & $2.3 \times 10^{7}$ \\
T1 & $1.8 \times 10^{7}$ & $3.7 \times 10^{3}$ & $2.3 \times 10^{7}$ & $8.2 \times 10^{3}$ \\
T2 & $1.8 \times 10^{7}$ & $3.8 \times 10^{3}$ & $2.3 \times 10^{7}$ & $8.1 \times 10^{3}$ \\
T3 & $1.8 \times 10^{7}$ & $3.3 \times 10^{3}$ & $2.3 \times 10^{7}$ & $8.5 \times 10^{3}$ \\
T4 & $1.8 \times 10^{7}$ & $3.2 \times 10^{3}$ & $2.3 \times 10^{7}$ & $8.0 \times 10^{3}$ \\
T5 & $1.8 \times 10^{7}$ & $3.6 \times 10^{3}$ & $2.3 \times 10^{7}$ & $8.4 \times 10^{3}$ \\
\hline
\end{tabular}

Sewage sludge solid wastes were collected over a period from the towns of Taman Koperasi and Taman Sri Nanding, Malaysia. Its moisture was estimated to be around 80$82 \%$. First the sludge was dewatered for two weeks prior to composting to moisture content of around $20-30 \%$. The partially dried material was sieved and cleaned before starting the composting operation. Furthermore, sawdust as an amendment was added to the dewatered sludge since the water content of the raw material for compost should not exceed $60 \%$ and typically should be between $50 \%$ and $60 \%$, in order to operate the system adequately. If the water content of the sludge was less than the optimal, due to the addition of sawdust, required amount of water was added to raise the water content to the optimal level. The organic raw materials were then transferred into the horizontal drum bioreactor (HDB) of 300L. The HDB is a totally enclosed vessel of $300 \mathrm{~L}$ capacity and made of PVC frame and clear PVC with a discharge window. The rotating drum unit consists of a cylinder of $0.7 \mathrm{~m}$ diameter and $1 \mathrm{~m}$ long and a working height of $1.5 \mathrm{~m}$ with rotation bearings on both sides. Refuse is fed in the middle of the drum. The retention time in the drum is usually 2 to 30 days after which the material is discharged. These materials are turned once every 4 hours. Air is usually supplied by blowing through holes. Water sprayer nozzles were placed above to adjust the moisture content and to prevent the material from becoming too dry. Agitation was provided by horizontal rotating arms.

Mixture of sewage and sawdust for seven experiments (control and T1 to T6) of weight $24 \mathrm{~kg}, 25 \mathrm{~kg}, 35 \mathrm{~kg}, 27 \mathrm{~kg}, 29 \mathrm{~kg}$ and $26.5 \mathrm{~kg}$ were prepared and composted for exactly $30,27,24,21,32$ and 30 days respectively in the HDB with a closed system to monitor the changes in temperature, $\mathrm{pH}$, and moisture content. The composting mass was aerated every 4 hours by air supplied through a compressor at $0.6 \mathrm{~L} / \mathrm{min} / \mathrm{kg}$. Moisture content was monitored throughout the composting period. Duplicate samples of $150 \mathrm{~g}$ each were removed every day 
during the experiments to analyze for $\mathrm{pH}$, moisture content and electrical conductivity measurement, and at days $0,3,6,9,12,15,18,21$, up to 32 days for chemical analysis.

\section{RESULTS AND DISCUSSION}

The presence of coliform bacteria is often used as an indicator of the overall sanitary quality of soil and water environments [15]. Use of an indicator such as coliforms, as opposed to the actual disease-causing organisms, is advantageous as the indicators generally occur at higher frequencies than the pathogens and are simpler and safer to detect. The average number of faecal coliforms was $2.3 \times 10^{7}$ bacteria/g waste dry weight at the beginning of the composting process, and decreased considerably to $8.2 \times 10^{3}, 8.1$ $\times 10^{3}, 8.5 \times 10^{3}, 8.0 \times 10^{3}$, and $8.4 \times 10^{3}$ bacteria/g, respectively for experiments $\mathrm{T} 1$ to T5. This decrease was presumably the result of raising temperature from $26^{\circ}$ to $42^{\circ}, 46^{\circ}$, $47^{\circ}, 49^{\circ}$ and $47^{\circ} \mathrm{C}$, for the experiments $\mathrm{T} 1, \mathrm{~T} 2, \mathrm{~T} 3, \mathrm{~T} 4$, and $\mathrm{T} 5$, respectively. It was observed that the changes in faecal coliforms during the composting process followed a pattern typical of other composting systems $[15,16]$. For the control experiment, there was no reduction, as the composting could not proceed in the raw sludge. The results of experiments $\mathrm{T} 1$ to $\mathrm{T} 5$ show that the sludge from sewage plants can be made safe by composting.

\subsection{Escherichia Coli}

Le Minor [17], reported that E. coli has been found to be the most representative bacterium in the group of faecal coli evolution. The number of E. coli cells showed a similar evolution (Table 3) to that of faecal coliforms. The phase of hygienisation was marked by a very significant decrease in the number of $E$. coli cell $\left(1.8 \times 10^{7}\right.$, to $3.7 \times$ $10^{3}, 3.8 \times 10^{3}, 3.3 \times 10^{3}, 3.2 \times 10^{3}$, and $3.6 \times 10^{3}$ bacteria/g for T1, T2, T3, T4, and T5 experiments respectively).

\subsection{Effects of Composting on Heavy Metals}

Composting has become a more acceptable alternative for the treatment of sewage sludge in many municipalities due to the potential use of the composting product for land application. The major limitation in general use of sewage municipal sludge compost is the high heavy metals content in the compost [4]. Accumulation of heavy metal contents such as $\mathrm{Zn}$ and $\mathrm{Cu}$ in plant tissues and soils following the application of sewage sludge compost is not an uncommon experience [18]. It should be used only for the production of non-food crops or non-leafy foods such as grains, fruits, or nuts, because fruiting parts of these plants usually contain lower metal concentrations than do vegetative parts [19].

The present study was conducted to evaluate the effect of composting process on the heavy metal content of the sewage sludge. Table 3 shows the effect of composting on heavy metal contents. The table also includes the standards acceptable in various countries. Total heavy metals contained in nitric-perchloric digestion extracts and those extractable with $0.005 \mathrm{M}$ DTPA (diethylene-triamine-pentaacetic acid), $0.5 \mathrm{M} \mathrm{CaCl}_{2}$ and $\mathrm{H}_{2} \mathrm{O}$ as mentioned in Materials and Experimental method sections, were measured by 
atomic absorption spectrometry. It can be seen from the figures, that there is a general reduction in the metal content after composting. In experiment T4, where $P$. chrysosporium and Tichoderma harzianum were used, the Cd reduction by composting is more than $50 \%$. Their reduction meets the requirement set by Spain but fails to meet the standards set by other countries because the sources of sewage sludge differ from other countries and the standards they use also differ. Similar trends were observed for other metals. No such standards are available for Malaysia.

The high amount of $\mathrm{Zn}$ extracted in experiment T2 and T5 made this most dangerous of all metals studied. This shows the danger of sewage sludge exposed to contamination by soluble metal salts. Lead and Cadmium were lower at the end time of composting for all experiments. They have the least amount left for experiments T3 and T4. The amount of $\mathrm{Zn}$ tended to be constant throughout the experiments, except T4 where it is of lower amount. This lower amount can be attributed to the drop in $\mathrm{pH}$ level at the end of experiment. As expected, the contaminated sewage sludge showed the highest levels for those metals added as metallic salts, during waste treatment process. The highest concentration was for $\mathrm{Fe}$ and the lowest for $\mathrm{Pb}$, showing that $\mathrm{Fe}$ is the most loosely bound to the sewage sludge organic matrix and $\mathrm{Pb}$ the most strongly bound. It is clear from the results of metals extracted, compared with the total metal content that composting renders part of the metal insoluble so that less passes into the most soluble extracts. This means that when the wastes have been composted there is less risk of the metals in the wastes being added to soils being used by plants.

\section{CONCLUSION}

A medium scale bioreactor (HDB) was developed and operated for the SSF of sewage sludge. The horizontal drum bioreactor is a promising equipment for growth of microorganisms ( $P$. chrysosporium, Trichderma harzianum, and Mucor hiemalis) in SSF and is worthy of further investigation, such as inducing auto-sterilization with a relatively high temperature $\left(60-70{ }^{\circ} \mathrm{C}\right)$ to rapid changing in biodegradation. For a successful composting process in a $\mathrm{HDB}$, the main problem for a small treatment plant is to dewater the sludge sufficiently. One possibility to deal with this is to mix the sludge with sawdust. Sawdust has low moisture content of $17 \%$ and high $\mathrm{C} / \mathrm{N}$ ratio 184. As dry bulking material it is the kind that degrades at the same rate as the sludge and is incorporated into the compost, no screening will be necessary. A mixture of various materials is possible, but the amount of sawdust should be at least 1:1.7 of the total volume. The best microorganism for composting was found to be Trichoderma harzianum and a mixture of $P$. chrysosporium and Trichoderma harzianum. The sanitation control program covered investigations of microbial community, bacteria and parasites in the composting material. The result was acceptable for Escherichia coli and faecal coliform. Heavy metal concentration was low and below the limit values. All parameters are lower than the regulations for sewage sludge for various countries. The concentration of hazardous organic substances in the compost was smaller than in average sewage sludge from treatment plants. The results presented in this work were statistically significant and compared favorably to those reported for SSF bioreactors used for mesophilic microorganisms [20]. Similarly, the moisture content variations were also significant. 
Table 4: Heavy metals content $(\mathrm{g} / \mathrm{kg})$ in compost, from HDB experiments

\begin{tabular}{|c|c|c|c|c|c|c|c|c|c|c|c|}
\hline $\begin{array}{l}\text { Parameter } \\
\mathrm{g} / \mathrm{kg}\end{array}$ & $\begin{array}{l}\text { Untreated } \\
\text { Sludge }\end{array}$ & $\begin{array}{l}\text { Standard } \\
\text { (Spain)* }\end{array}$ & $\begin{array}{l}\text { Standard } \\
\text { (France) }\end{array}$ & $\begin{array}{l}\text { Standard } \\
\text { (Germany) }\end{array}$ & $\begin{array}{l}\text { Standard } \\
\text { (Italy) }\end{array}$ & $\begin{array}{l}\text { Standard } \\
\text { (Austria) }\end{array}$ & $\begin{array}{l}\text { Compost } \\
\text { T1 }\end{array}$ & $\begin{array}{l}\text { Compost } \\
\text { T2 }\end{array}$ & $\begin{array}{l}\text { Compost } \\
\text { T3 }\end{array}$ & $\begin{array}{l}\text { Compost } \\
\text { T4 }\end{array}$ & $\begin{array}{c}\text { Compost } \\
\text { T5 }\end{array}$ \\
\hline $\mathrm{Cd}$ & $\begin{array}{c}0.47 \pm \\
0.0115^{\mathrm{a}}\end{array}$ & 0.4 & 0.008 & 0.015 & 0.015 & 0.004 & $\begin{array}{c}0.29 \pm \\
0.00577\end{array}$ & $\begin{array}{c}0.26 \pm \\
0.00577\end{array}$ & $\begin{array}{c}0.23 \pm \\
0.00577\end{array}$ & $\begin{array}{c}0.2 \pm \\
0.00577\end{array}$ & $\begin{array}{c}0.27 \pm \\
0.00577\end{array}$ \\
\hline $\mathrm{Fe}$ & $\begin{array}{l}19.7 \pm \\
0.252\end{array}$ & 40 & $\mathrm{Nd}$ & $\mathrm{Nd}$ & $\mathrm{Nd}$ & $\mathrm{Nd}$ & $12.1 \pm 0.1$ & $14 \pm 0.98$ & $\begin{array}{c}11.2 \pm \\
0.12\end{array}$ & $\begin{array}{l}8.98 \pm \\
0.057\end{array}$ & $\begin{array}{c}9.89 \pm \\
0.008\end{array}$ \\
\hline $\mathrm{Cu}$ & $\begin{array}{c}0.604 \pm \\
0.023\end{array}$ & 1.75 & $\mathrm{Nd}$ & 0.1 & 0.3 & 0.4 & $\begin{array}{c}0.49 \pm \\
0.00577\end{array}$ & $\begin{array}{l}0.334 \pm \\
0.0008\end{array}$ & $\begin{array}{c}0.548 \pm \\
0.015\end{array}$ & $\begin{array}{l}0.22 \pm \\
0.0057\end{array}$ & $\begin{array}{c}0.500 \pm \\
0.0057\end{array}$ \\
\hline $\mathrm{Zn}$ & $\begin{array}{l}1.84 \pm \\
0.115\end{array}$ & 4.0 & $\mathrm{Nd}$ & 0.4 & 0.5 & 1.0 & $\begin{array}{c}0.275 \pm \\
0.0008\end{array}$ & $\begin{array}{l}1.11 \pm \\
0.0088\end{array}$ & $\begin{array}{c}1.028 \pm \\
0.0005\end{array}$ & $\begin{array}{c}0.98 \pm \\
0.008\end{array}$ & $\begin{array}{c}1.5 \pm \\
0.0577\end{array}$ \\
\hline $\mathrm{Cr}$ & $\begin{array}{c}0.317 \pm \\
8.819 \times 10^{-4}\end{array}$ & $\mathrm{Nd}$ & $\mathrm{Nd}$ & $\mathrm{Nd}$ & $\mathrm{Nd}$ & $\mathrm{Nd}$ & $\begin{array}{c}0.25 \pm \\
0.011\end{array}$ & $\begin{array}{l}0.192 \pm \\
0.0014\end{array}$ & $\begin{array}{c}0.1 \pm \\
0.0115\end{array}$ & $\begin{array}{l}0.08 \pm \\
0.0001\end{array}$ & $\begin{array}{c}0.217 \pm \\
0.0008\end{array}$ \\
\hline $\mathrm{Pb}$ & $\begin{array}{l}0.300 \pm \\
0.0577\end{array}$ & 1.2 & 0.8 & 0.15 & 0.14 & 0.5 & $\begin{array}{c}0.28 \pm \\
0.00577\end{array}$ & $\begin{array}{l}0.195 \pm \\
0.0014\end{array}$ & $\begin{array}{c}0.189 \pm \\
0.0015\end{array}$ & $\begin{array}{c}0.175 \pm \\
0.0012\end{array}$ & $\begin{array}{c}0.200 \pm \\
0.0014\end{array}$ \\
\hline $\mathrm{Ca}$ & $\begin{array}{l}16.5 \pm \\
0.2887\end{array}$ & $\mathrm{Nd}$ & $\mathrm{Nd}$ & $\mathrm{Nd}$ & $\mathrm{Nd}$ & $\mathrm{Nd}$ & $\begin{array}{l}15.2 \pm \\
0.172\end{array}$ & $\begin{array}{l}14.3 \pm \\
0.088\end{array}$ & $\begin{array}{l}13.2 \pm \\
0.145\end{array}$ & $\begin{array}{l}12.3 \pm \\
0.088\end{array}$ & $\begin{array}{l}13.6 \pm \\
0.173\end{array}$ \\
\hline
\end{tabular}

(William, 2001) [22]

${ }^{a}$ Mean \pm standard error

$\mathrm{Nd}=$ Not determined 
For better rotation and passing air for more active biooxidative phase, direct current (DC) motor on different intervals recommends rotating slowly the HDB. No turning is required during the mesophilic phase. Air inlet and outlet are supposed to be placed at opposite positions for better aeration of the SSF. The aeration required is provide by a blower operated in the positive mode at $0.6 \mathrm{~L} / \mathrm{min} / \mathrm{kg}$ and the air blowing stops in the maturation phase to allow the compost maturation. Heavy metal concentration was low and below the limit values of the various countries regulation after composting. To the author's knowledge, there is no standard specification for compost maturity.

\section{REFRERENCE}

[1] E. Jeremy, Hall, and A. Zmyslowska. "Development of sludge treatment and disposal strategies for large conurbation: case study". Warsaw Journal of Water Science and Technology. 1998, 36 (11), 291-298.

[2] G. T. Chobanoglous. "Wastewater Engineering, treatment, disposal and reuse". Tata McGraw-Hill. New Delhi: 1987; 119-123.

[3] A. Din, and M. Hamid. "The Management of Municipal wastewater Sludge in Malaysia", Paper presented at IEM talk on Sewage Sludge Management Issues, $18^{\text {th }}$ August 1998, Petaling Jaya 1-11.

[4] J. M. Fang; C. W. Wong; X. G. Li; and H. M. Wong. "Changes in Biological Parameters during Co-Composting of sewage sludge and coal ash Residues". Bioresource Technology 1998, 64, 55-61.

[5] L. T. Richard. "Composting Strategies for high Moisture Manures". Manure Management in Harmony with the Environment and Society Conference. The Soil and Water Conservation Society, February 10-12. 1996; 135-138. West North Central Region, Ames, IA.

[6] J. M. Fang; and C. W. Wong. "Effects of lime amendment on availability of heavy metals and maturation in sewage sludge composting". Environmental Pollution. 1999, 106, 83-89.

[7] T. R. Guar, and A.L. Haug. "Sludge Composting: A Discussion of Engineering Principles". Compost Science. 1978, 10-14.

[8] Standard Method for the Examination of water and wastewater. 15th edition APHA AWWA. WPCI, 1980; 383-385.

[9] J. L. Sikora, M. Ramirez; and T. Troeschel. "Laboratory composure for simulation studies". J. Environmental Quality. 1983, 12, 219-224.

[10] R. Hachica, N. Jedidi; and A. Hassen. "Aspects hygieniques de la fermentation aerobies des dechets urbains dans le contexte tunisien”. Arch. Ins. Pasteur Tunis 1993, 70, 13-20.

[11] H. J. Zar. "Biostatistical Analysis", Prentice Hall International, Englewood Cliffs, NJ; 1996.

[12] P. E. Dunnigan, and P.R. Dick. "Nutrients and coliform losses in runoff from fertilized and sewage sludge treated soil". Journal of Environmental quality. 1980, 9, 243-250.

[13] C. A. Bruggerman, and Mostaghimi. "Sludge application effects on runoff, infiltration and water quality". Water Resource bull. 1993, 29, 15-26.

[14] J. Jenkins. “The Humanure”, $2^{\text {nd }}$ ed. Jenkins Publishing, Grove City, Pa. 1999; 15-19.

[15] A. Hassen; K. Belguith; N. Jedidi; A. Cherif. and M. B. Cherif. "Microbial characterization during composting of municipal solid waste". Journal of Bioresource Technology. 2001, 80, 217-225. 
[16] J. C. Hay. "Pathogen Destruction and Biosolids Composting”. Journal of BioCycle. 1996, 6776.

[17] L. Le Minor. "Escherichia coli. Bacteriologie Medicale". Flammarion Medicine Sciences. Paris. 1984, 240-253.

[18] T. J. Sims, and S. J. Kline. "Chemical fractionation and plant uptake of heavy metals in soil amended with co-composted sewage sludge". Journal of Environmental quality. 1991, 20, 387-395.

[19] J. Jing; and J. T. Logan. "Effects of sewage sludge cadmium concentration on chemical extractability and plant uptake". Journal of Environmental Quality. 1992, 21, 73-81.

[20] E. Kalogeris, G. Fountoukides, D. Kekos. and J. B. Macris. "Design of a solid-state bioreactor for thermophilic microorganisms". Bioresource Technology. 1999, 67, 313-315.

[21] C. D. Adriano, L. A. Page, A. A. Alseewi, C. A. Chang, and I. Straughan. "Utilization and disposal of fly ash and other residues in terrestrial ecosystem: A review". J. Environmental Quality. 1980, 9, 333-334.

[22] F. William, and Brinton. "An International Look At Compost Standards. Journal of BioCycle”. 2001, 74-76. 